\title{
Reformatoryjny wyrok Naczelnego Sądu Administracyjnego pięć lat po reformie
}

\section{Wprowadzenie}

Przepisy Ustawy z dnia 9 kwietnia 2015 r. o zmianie ustawy - Prawo o postępowaniu przed sądami administracyjnymi ${ }^{1}$ wprowadziły wiele modyfikacji do procedury sądowoadministracyjnej, zmieniając jej systemowy kształt w znacznym stopniu. Aby uświadomić sobie zakres zmian wprowadzonych powyższą nowelą do Ustawy z dnia 30 sierpnia 2002 r. Prawo o postępowaniu przed sądami administracyjnymi², należy wskazać, że nowelizacja ta była najobszerniejszą zmianą postępowania sądowoadministracyjnego od 2002 r., kiedy to prawodawca, uchwalając tę ustawę, zdecydował się wprowadzić dwuinstancyjność postępowania sądowoadministracyjnego ${ }^{3}$. Spośród licznie wprowadzonych modyfikacji powyższa nowelizacja znacznie rozszerzyła możliwość reformatoryjnego orzekania przez Naczelny Sąd Administracyjny (NSA). Nowela ta weszła w życie 15 sierpnia 2015 r. - procedura sądowoadministracyjna w tym odmienionym systemowo kształcie obowiązuje zatem od pięciu lat, co z kolei pozwala na dokonanie oceny funkcjonowania wprowadzonej przez ustawodawcę regulacji.

* Radosław Petrus, magister prawa, e-mail: radosław.petrus@gmail.com, https:// orcid.org/0000-0003-2921-4830.

${ }^{1}$ Dz.U. 2015, poz. 658.

${ }^{2}$ Dz.U. 2019, poz. 2325, dalej „p.p.s.a.”.

${ }^{3}$ M. Pogoński, Najważniejsze zmiany w procedurze sądowoadministracyjnej obowiąujace od 15 sierpnia 2015 r., "Przegląd Podatkowy” 2015, nr 10, s. 19. 
W niniejszym opracowaniu podjęta zostanie próba dokonania oceny wprowadzonej nowelizacji w zakresie rozszerzenia reformatoryjnych kompetencji orzeczniczych NSA z jednoczesnym wskazaniem, jaki miała ona wpływ na praktykę orzeczniczą.

\section{Reformatoryjne orzekanie przez Naczelny Sąd Administracyjny przed 15 sierpnia $2015 \mathrm{r}$.}

W razie uwzględniania skargi kasacyjnej NSA, zgodnie z przepisem art. $185 \S 1$ p.p.s.a., uchyla zaskarżone orzeczenie w całości lub w części i przekazuje sprawę do ponownego rozpoznania sądowi, który wydał zaskarżone orzeczenie. Wspomniany rodzaj wydawanego przez NSA wyroku odzwierciedla istotę kasacyjnego modelu zasady dwuinstancyjności postępowania sądowoadministracyjnego ${ }^{4}$.

Jednakże w przypadku uwzględnienia skargi kasacyjnej wniesionej od orzeczenia wojewódzkiego sądu administracyjnego p.p.s.a. dopuszcza ponadto możliwość wydania przez NSA wyroku reformatoryjnego. W doktrynie od dawna bowiem podkreślano, że wyposażenie sądów odwoławczych w kompetencje do orzekania reformatoryjnego wpływa na przyspieszenie postępowania ${ }^{5}$.

Kwestię reformatoryjnego orzeczenia NSA reguluje art. 188 p.p.s.a. W brzmieniu sprzed 15 sierpnia 2015 r. przepis ów stanowił:

Jeżeli nie ma naruszeń przepisów postępowania, które mogły mieć istotny wpływ na wynik sprawy, a zachodzi jedynie naruszenie prawa materialnego, Naczelny Sąd Administracyjny może uchylić zaskarżone orzeczenie i rozpoznać skargę. W tym przypadku Sąd orzeka na podstawie stanu faktycznego przyjętego w zaskarżonym wyroku.

Analizując treść pierwotnego brzmienia przepisu art. 188 p.p.s.a., należało uznać, że po uwzględnieniu skargi kasacyjnej możliwość wydania przez NSA wyroku reformatoryjnego zależna była od spełnienia dwóch przesłanek: pozytywnej i negatywnej ${ }^{6}$. Sąd musiał bowiem ustalić, po

${ }^{4}$ B. Adamiak, J. Borkowski, Postępowanie administracyjne i sadowoadministracyjne, Warszawa 2017, s. 573.

${ }^{5}$ W. Siedlecki, Postępowanie cywilne. Zarys wykładu, Warszawa 1977, s. 367.

${ }^{6}$ J. Firlus, A. Ozimek, Model skargi kasacyjnej w świetle projektu ustawy nowelizujacej ustawe - Prawo o postępowaniu przed sadami administracyjnymi, „Przegląd Prawa Publicznego" 2015, nr 2, s. 64, i przywołana tam literatura. 
pierwsze, że w danej sprawie zachodzi jedynie naruszenie przepisów prawa materialnego oraz, po drugie, że w danej sprawie nie ma naruszeń przepisów postępowania, które mogły mieć istotny wpływ na wynik sprawy ${ }^{7}$. Sam sposób sformułowania powyższych przesłanek wskazywał na fakt, że wyposażenie Naczelnego Sądu Administracyjnego w kompetencje do orzekania reformatoryjnego zostało pomyślane jako wyjątek od zasadniczo kasacyjnych uprawnień orzeczniczych tego sądu' ${ }^{8}$. Przesłanki te, jak zauważa W. Piątek, miały ściśle określony, kazuistyczny kształt $^{9}$. Jak słusznie podkreśla R. Hauser, nadzwyczajny charakter instytucji procesowej, jaką stanowi wyrok reformatoryjny, obrazuje choćby fakt użycia przez ustawodawcę pojęć znacznie zawężających możliwość jej zastosowania, tj. „istotny wpływ” czy „jedynie”"10. Przy analizie przepisu art. 188 p.p.s.a. w brzmieniu sprzed 15 sierpnia 2015 r. nie można zapomnieć, że nawet po spełnieniu opisanych powyżej przesłanek Naczelny Sąd Administracyjny nie był zobligowany do wydania wyroku reformatoryjnego. Wskazany przepis w poprzednim brzmieniu nadawał bowiem NSA jedynie możliwość skorzystania z opisanej kompetencji, na co wprost wskazywał zwrot: „Naczelny Sąd Administracyjny może uchylić zaskarżone orzeczenie i rozpoznać skargę". Takie sformułowanie przysługujących NSA kompetencji do wydania wyroku reformatoryjnego nadawało tymże kompetencjom charakter fakultatywny. To z kolei oznaczało, że nawet pomimo zaistnienia w danej sprawie sądowoadministracyjnej przesłanek do wydania orzeczenia reformatoryjnego, NSA mógł skorzystać z kompetencji czysto kasacyjnych, tj. uchylić zaskarżone orzeczenie i przekazać sprawę do ponownego rozpoznania sądowi pierwszej instancji ${ }^{11}$.

Nie dziwią zatem podnoszone wówczas przez doktrynę twierdzenia, że omawiana regulacja - mówiąc powściągliwie - nie jest regulacją

${ }^{7}$ Przesłanka związana z brakiem naruszenia przepisów postępowania, które mogło mieć istotny wpływ na wynik sprawy, powiązana była ściśle z ówczesnym brzmieniem zdania drugiego przepisu art. 188 p.p.s.a., tj. z koniecznością oparcia przez NSA rozstrzygnięcia na stanie faktycznym sprawy ustalonym przez sąd administracyjny pierwszej instancji.

${ }^{8}$ H. Knysiak-Molczyk, T. Woś, Sądownictwo administracyjne pięć lat po reformie, „Przegląd Prawa Publicznego" 2010, nr 1, s. 16.

${ }^{9}$ W. Piątek, Wyrok reformatoryjny Naczelnego Sąu Administracyjnego, "Zeszyty Naukowe Sądownictwa Administracyjnego" 2017, nr 2, s. 11.

${ }^{10} \mathrm{R}$. Hauser, Wstępne zatożenia nowelizacji ustawy - Prawo o postępowaniu przed sądami administracyjnymi, „Państwo i Prawo” 2013, z. 2, s. 23.

${ }^{11}$ H. Knysiak-Molczyk, T. Woś, op. cit., s. 16-17. 
doskonałą ${ }^{12}$. Przystępując do rozważań na temat uprawnień orzeczniczych sądów administracyjnych - a więc sądów dysponujących kompetencjami kasacyjnymi - nie można zapomnieć, że jedną z wad kasacyjnego modelu orzekania jest rozpatrywanie tej samej sprawy na przemian przez organy administracji i sądy administracyjne bez jej ostatecznego, merytorycznego zakończenia ${ }^{13}$. Wąskie określenie uprawnień NSA do wydania orzeczenia reformatoryjnego skutkować będzie tym, że nawet pomimo uwzględnienia skargi kasacyjnej strona wciąż będzie daleka od uzyskania orzeczenia rozstrzygającego sprawę co do istoty. Nie bez powodu zatem $\mathrm{w}$ doktrynie pojawiały się zarzuty do ówczesnego brzmienia przepisu art. 188 p.p.s.a., przez które starano się uświadomić ustawodawcy, że uchylenie zaskarżonego orzeczenia (zamiast jego zmiany) prowadzi często do nieuzasadnionego przedłużenia postępowania sądowego przez mnożenie instancji sądowych ${ }^{14}$. Ten mankament tj. rozpatrywanie danej sprawy przez organy i sądy administracyjne co najwyżej przybliżające stronę do ostatecznego jej rozstrzygnięcia, wynikający z przesadnego przywiązania do kasacyjnej formuły orzekania przez sądy administracyjne - Z. Kmieciak nazwał obrazowo efektem jo-jo ${ }^{15}$. Z kolei w obliczu wąskiego ukształtowania kompetencji NSA do wydawania wyroków reformatoryjnych H. Knysiak-Molczyk i T. Woś podnosili, że brak uzasadnienia do przyjętego w p.p.s.a. ograniczenia możliwości orzekania reformatoryjnego przez sąd drugiej instancji ${ }^{16}$. Uwzględniając fakt, że w postępowaniu przed NSA odpowiednie zastosowanie mają przepisy o postępowaniu przed sądami administracyjnymi pierwszej instancji, w związku z czym NSA ma realną możliwość usunięcia większości wad postępowania przed sądem a quo, autorzy ci wskazywali, że „konieczność wydania orzeczenia kasacyjnego powinna być powiązana $z$ wadami powodującymi nieważność postępowania przed sądem administracyjnym pierwszej instancji, w pozostałych przypadkach sąd odwoławczy powinien mieć obowiązek dążenia do definitywnego zakończenia postępowania przez wydanie orzeczenia o charakterze

${ }^{12}$ Ibidem, s. 16.

${ }^{13}$ A. Skoczylas, Modele uprawnień orzeczniczych sądów administracyjnych w Europie, „Państwo i Prawo" 2012, z. 10, s. 23.

${ }^{14}$ R. Hauser, op. cit., s. 23.

${ }^{15} \mathrm{Z}$. Kmieciak, O merytorycznym orzekaniu przez sądy administracyjne raz jeszcze, "Gdańskie Studia Prawnicze - Przegląd Orzecznictwa" 2015, nr 4, s. 17; idem, Merytoryczne orzekanie przez sady administracyjne w świetle konstytucyjnej zasady podziału władz, „Przegląd Legislacyjny" 2015, nr 2, s. 19.

${ }^{16}$ H. Knysiak-Molczyk, T. Woś, op. cit., s. 16. 
reformatoryjnym"17. Tylko na marginesie wypada zaznaczyć, że już na etapie tworzenia prawa postępowania przed sądami administracyjnymi starano się podkreślić potrzebę wyposażenia sądów administracyjnych, w tym NSA, w szerokie kompetencje do orzekania merytorycznego, jako remedium na ewentualną przewlekłość postępowañ ${ }^{18}$.

Biorąc pod uwagę powyższe, należy uznać, że poprzednio obowiązująca regulacja w zakresie uprawnień NSA do reformatoryjnego orzekania nie była regulacją wolną od wad, zwłaszcza jeśli chodzi o względy szybkości oraz efektywności postępowania.

Stąd też w doktrynie rozszerzenie uprawnień NSA do wydawania orzeczeń reformatoryjnych postrzegano jako szansę na skrócenie czasu trwania postępowań sądowych ${ }^{19}$. Ta sama idea przyświecała ustawodawcy, który w uzasadnieniu do projektu ustawy z dnia 9 kwietnia 2015 r. o zmianie ustawy - Prawo o postępowaniu przed sądami administracyjnymi wskazał, że rozszerzenie możliwości reformatoryjnego orzekania przez NSA i wprowadzenie go jako zasady usprawni i przyspieszy postępowanie sądowoadministracyjne ${ }^{20}$.

\section{Obecny kształt uprawnień NSA do wydawania orzeczeń reformatoryjnych}

W odpowiedzi na powyższe postulaty ustawodawca znacznie zmodyfikował treść przepisu art. 188 p.p.s.a., nadając mu nowe, następujące brzmienie:

Naczelny Sąd Administracyjny w razie uwzględnienia skargi kasacyjnej, uchylając zaskarżone orzeczenie, rozpoznaje skargę, jeżeli uzna, że istota sprawy jest dostatecznie wyjaśniona.

Obecny kształt powyższej regulacji znacznie rozszerzył kompetencje NSA do wydawania orzeczeń reformatoryjnych. Jedną z najważniejszych

${ }^{17}$ Ibidem.

${ }^{18}$ Stanowisko Krajowej Rady Sądownictwa z 17 maja 2001 r. m.in. do projektu p.p.s.a. - uwagi do art. 173 i n., uwaga nr 3 (http://orka.sejm.gov.pl/Druki4ka.nsf/ wgdruku/19, dostęp: 13 VII 2020).

${ }^{19}$ Ibidem, s. 16; R. Hauser, op. cit., s. 23-24; A. Skoczylas, op. cit., s. 31-32; J. Firlus, A. Ozimek, op. cit., s. 65-66.

${ }^{20}$ Uzasadnienie do projektu ustawy z dnia 9 kwietnia 2015 r. o zmianie ustawy - Prawo o postępowaniu przed sądami administracyjnymi, uzasadnienie zmian do art. 188, s. 28, druk sejmowy nr 1633/VII kadencja, http://www.sejm.gov.pl/Sejm7.nsf/druk. xsp?nr=1633 (dostęp: 13 VII 2020). 
modyfikacji przepisu art. 188 p.p.s.a. jest zmiana charakteru kompetencji NSA w powyższym zakresie. Obecna treść przepisu wskazuje, że wydanie tego rodzaju orzeczenia pomyślano jako zasadę. Po spełnieniu określonych w przepisie przesłanek NSA ma obowiązek uchylić zaskarżone orzeczenie i orzec bezpośrednio co do samej skargi wniesionej do wojewódzkiego sądu administracyjnego ${ }^{21}$. Na obligatoryjny charakter reformatoryjnego orzekania przez NSA wskazuje użyte przez ustawodawcę sformułowanie, zgodnie z którym NSA „w razie uwzględnienia skargi kasacyjnej, uchylając zaskarżone orzeczenie, rozpoznaje skargę"22. Takie stanowisko potwierdza również NSA, który wskazał, że wydanie orzeczenia reformatoryjnego nie jest zależne od wniosku strony wnoszącej skargę kasacyjną ${ }^{23}$.

Ustawodawca zmienił także przesłanki zastosowania omawianego przepisu. Dwie przesłanki, mające ściśle określony, kazuistyczny charakter (brak wystąpienia naruszenia przepisów postępowania przy jednoczesnym naruszeniu prawa materialnego), zastąpiono jedną przesłanką o niedookreślonym brzmieniu ${ }^{24}$. Obecnie bowiem NSA w razie uwzględnienia skargi kasacyjnej orzeka reformatoryjnie, jeżeli uzna, że istota sprawy jest dostatecznie wyjaśniona.

Zgodnie natomiast $\mathrm{z}$ formułowanymi $\mathrm{w}$ doktrynie zapatrywaniami istota sprawy jest dostatecznie wyjaśniona, gdy na podstawie zgromadzonego w aktach sprawy materiału dowodowego NSA jest w stanie jednoznacznie ocenić, czy zaskarżony akt albo czynność (bezczynność, przewlekłe prowadzenie postępowania) są zgodne z prawem ${ }^{25}$. J. Firlus i A. Ozimek dostateczne wyjaśnienie istoty sprawy sprowadzają z kolei do ustalenia, czy rozstrzygnięcie sprawy przez organ administracji publicznej zostało prawidłowo skontrolowane przez sąd pierwszej instancji ${ }^{26}$. Możliwość wydania wyroku reformatoryjnego NSA w swoim orzecznictwie dostrzega z kolei w odniesieniu do spraw, w których uchybienia sądu pierwszej instancji nie polegały na pominięciu istotnych dla sprawy kwestii bądź konieczności ponownego ich zbadania ${ }^{27}$. W innym

${ }^{21}$ Ibidem.

22 J. Firlus, A. Ozimek, op. cit., s. 65; M. Pogoński, op. cit., s. 23.

${ }^{23}$ Wyrok NSA z 19 XII 2018 r., sygn. II FSK 3541/16, LEX nr 2617519.

${ }^{24}$ W. Piatek, op. cit., s. 11.

${ }^{25}$ R. Hauser, A. Skoczylas, W. Piątek, Środki odwoławcze w postępowaniu sądowoadministracyjnym w świetle ustawy nowelizującej z dnia 9 kwietnia 2015 r. - analiza najistotniejszych zmian, "Zeszyty Naukowe Sądownictwa Administracyjnego" 2015, nr 4, s. 17.

${ }^{26}$ J. Firlus, A. Ozimek, op. cit., s. 67.

${ }^{27}$ Wyrok NSA z 26 VI 2019 r., sygn. I FSK 491/19, LEX nr 2688072. 
orzeczeniu NSA wskazał natomiast, że z dostatecznie wyjaśnioną istotą sprawy można mieć do czynienia, gdy NSA jest w stanie uchwycić i wypowiedzieć się co do sedna zasadniczego sporu prawnego przedstawionego mu do oceny, chociaż sprawa w znaczeniu materialnoprawnym wymagać będzie jeszcze rozstrzygnięcia organu administracji publicznej w oparciu o tę wypowiedź i stosownych do niej ustaleń faktycznych ${ }^{28}$. Innym razem NSA poprzestał na stwierdzeniu, że można przyjąć, iż istota sprawy jest dostatecznie wyjaśniona, gdy błędy, których dopuściły się organy administracyjne oraz sąd pierwszej instancji, nie budzą wątpliwości ${ }^{29}$.

Podsumowując powyższe, należy za R. Hauserem wskazać, że na skutek wprowadzonych zmian NSA zawsze ma możliwość merytorycznego rozstrzygnięcia kwestii objętych zaskarżeniem, kierując się przede wszystkim potrzebą usunięcia przeszkód hamujących sprawne rozpoznanie sprawy ${ }^{30}$. Oznacza to, że jeśli tylko NSA, po uwzględnieniu skargi kasacyjnej, uzna, iż istota procedowanej sprawy sądowoadministracyjnej jest dostatecznie wyjaśniona, obowiązany jest do wydania wyroku reformatoryjnego zgodnie z przepisem art. 188 p.p.s.a., a nie rozstrzygnięcia o charakterze kasacyjnym przewidzianego w przepisie art. $185 \S 1$ p.p.s.a.

\section{Podsumowanie}

Pięcioletnie obowiązywanie nowych, szerszych kompetencji NSA do orzekania reformatoryjnego daje możliwość oceny powyższej regulacji. Uwzględnienie przez ustawodawcę formułowanych przez doktrynę postulatów ${ }^{31}$ przyniosło pozytywny skutek. $W$ istocie nowelizacja p.p.s.a., w ramach której ustawodawca rozszerzył uprawnienia NSA do wydawania orzeczeń reformatoryjnych oraz uczynił z tego rodzaju orzeczenia zasadę, sprawiła, że obecnie NSA coraz częściej stosuje przepis art. 188 p.p.s.a. Jak bowiem wynika ze statystyk, w 2014 r. a zatem rok przed nowelizacją - spośród 3395 uwzględnionych przez NSA skarg kasacyjnych Sąd orzekał reformatoryjnie jedynie w 1116 przypadkach, co z kolei oznacza, że uwzględniając skargę kasacyjna, korzystał z przepisu art. 188 p.p.s.a. zaledwie w ok. 33\% przypadków ${ }^{32}$.

\footnotetext{
${ }^{28}$ Wyrok NSA z 18 V 2016 r., sygn. I FSK 2085/14, LEX nr 2063889.

${ }^{29}$ Wyrok NSA z 3 III 2017 r., sygn. II OSK 3066/15, LEX nr 2299902.

${ }^{30}$ R. Hauser, op. cit., s. 23.

${ }^{31}$ Ibidem, s. 24; A. Skoczylas, op. cit., s. 31; H. Knysiak-Molczyk, T. Woś, op. cit., s. 16.

32 Statystyki NSA za rok 2014 - Skargi kasacyjne od orzeczeń sądu I instancji 2014 wg WSA, http://www.nsa.gov.pl/statystyki-nsa.php (dostęp: 13 VII 2020).
} 
Natomiast już w 2016 r. ${ }^{33}$ spośród 4089 uwzględnionych skarg kasacyjnych NSA korzystał z przepisu art. 188 p.p.s.a. w 2340 przypadkach, co oznacza, że orzekał reformatoryjnie w ok. 57\% przypadków ${ }^{34}$. W kolejnych latach wynik ten wynosił odpowiednio $58 \%^{35} \mathrm{w} 2017$ r., $62 \%{ }^{36}$ w 2018 r. i $67 \%{ }^{37}$ w 2019 r.

Biorąc pod uwagę powyższe statystyki, należy uznać, że z roku na rok NSA coraz częściej korzysta z wprowadzonych w 2015 r. rozszerzonych uprawnień do orzekania reformatoryjnego. Oczywiste jest, że przyczynia się do tego przede wszystkim fakt uczynienia z orzeczenia reformatoryjnego zasady, co zresztą było początkowym założeniem ustawodawcy ${ }^{38}$. Nie można jednak umniejszać wprowadzanych zmian, dzięki nim bowiem droga do uzyskania przez stronę wnoszącą skargę kasacyjną orzeczenia rozstrzygającego jej sprawę co do istoty została znacznie skrócona. W ich wyniku zmniejszona została liczba spraw, w których po rozpoznaniu przez NSA skargi kasacyjnej i wydaniu przez ten sąd orzeczenia dochodziło do przedłużenia postępowania sądowego przez mnożenie instytucji sądowych ${ }^{39}$.

\section{REFORMATORY JUDGMENT OF THE SUPREME ADMINISTRATIVE COURT FIVE YEARS AFTER THE REFORM}

\section{Sum mary}

The study refers to the amendment of the Law on Proceedings before Administrative Courts, implemented on 15 August 2015. Within the framework of the above amendment, significant changes were made to the administrative court procedure. According to the assumptions of the legislator, these changes were to contribute to the simplification and acceleration of administrative court proceedings. Among a number of modifications introduced to the administrative court procedure, it

\footnotetext{
${ }^{33}$ Rok 2016 był pierwszym pełnym rokiem obowiązywania nowelizacji.

${ }^{34}$ Statystyki NSA za rok 2016 - Skargi kasacyjne od orzeczeń sądu I instancji 2016 wg WSA, http://www.nsa.gov.pl/statystyki-nsa.php (13 VII 2020).

${ }^{35}$ Statystyki NSA za rok 2017 - Skargi kasacyjne od orzeczeń sądu I instancji 2017 wg WSA, http://www.nsa.gov.pl/statystyki-nsa.php (dostęp: 13 VII 2020).

${ }^{36}$ Statystyki NSA za rok 2018 - Skargi kasacyjne od orzeczeń sądu I instancji 2018 wg WSA, http://www.nsa.gov.pl/statystyki-nsa.php (dostęp: 13 VII 2020).

${ }^{37}$ Statystyki NSA za rok 2019 - Skargi kasacyjne od orzeczeń sądu I instancji 2019 wg WSA, http://www.nsa.gov.pl/statystyki-nsa.php (dostęp: 13 VII 2020).

${ }^{38}$ Uzasadnienie do projektu ustawy z dnia 9 kwietnia 2015 r. o zmianie ustawy - Prawo o postępowaniu przed sądami administracyjnymi, uzasadnienie zmian do art. 188, s. 28.

${ }^{39}$ R. Hauser, op. cit., s. 23.
} 
is worth noting in particular the extension of the competences of the Supreme Administrative Court (NSA) in the area of reformatory judgment. As a result of the amendment, the prerequisites for issuing a reformatory ruling have changed. Moreover, the nature of the provision has been changed from an optional to an obligatory one and such a ruling has been made a rule. The amended administrative court procedure has been in force for five years, which makes it possible to evaluate the regulation introduced by the legislator. The author compares the principles of reformatory judgment in force before and after the amendment and attempts to evaluate the regulation from the perspective of the five years it Has been In force. The study also contains statistics showing the impact of the amendment on case law. The extension of the competence of the Supreme Administrative Court in the area of reformatory adjudication was one of the most significant changes introduced to the Law on Proceedings before Administrative Courts since the beginning of the Act.

Keywords: NSA reformatory judgment - NSA reformatory ruling - NSA reformatory adjudication

\section{LITERATURA}

Adamiak B., Borkowski J., Postępowanie administracyjne i sądowoadministracyjne, Warszawa 2017.

Firlus J., Ozimek A., Model skargi kasacyjnej w świetle projektu ustawy nowelizującej ustawe - Prawo o postępowaniu przed sadami administracyjnymi, „Przegląd Prawa Publicznego" 2015, nr 2.

Hauser R., Wstępne założenia nowelizacji ustawy - Prawo o postępowaniu przed sądami administracyjnymi, "Państwo i Prawo” 2013, z. 2.

Hauser R., Skoczylas A., Piątek W., Środki odwoławcze w postępowaniu sądowoadministracyjnym w świetle ustawy nowelizującej z dnia 9 kwietnia 2015 r. - analiza najistotniejszych zmian, "Zeszyty Naukowe Sądownictwa Administracyjnego" 2015, nr 4.

Kmieciak Z., Merytoryczne orzekanie przez sądy administracyjne w świetle konstytucyjnej zasady podziatu władz, "Przegląd Legislacyjny” 2015, nr 2.

Kmieciak Z., O merytorycznym orzekaniu przez sądy administracyjne razjeszcze, "Gdańskie Studia Prawnicze - Przegląd Orzecznictwa" 2015, nr 4.

Knysiak-Molczyk H., Woś T., Sądownictwo administracyjne pięć lat po reformie, „Przegląd Prawa Publicznego" 2010, nr 1.

Piątek W., Wyrok reformatoryjny Naczelnego Sądu Administracyjnego, "Zeszyty Naukowe Sądownictwa Administracyjnego" 2017, nr 2.

Pogoński M., Najważniejsze zmiany w procedurze sądowoadministracyjnej obowiazujace od 15 sierpnia 2015 r., "Przegląd Podatkowy” 2015, nr 10.

Siedlecki W., Postępowanie cywilne. Zarys wykładu, Warszawa 1977.

Skoczylas A., Modele uprawnień orzeczniczych sądów administracyjnych w Europie, „Państwo i Prawo" 2012, z. 10. 


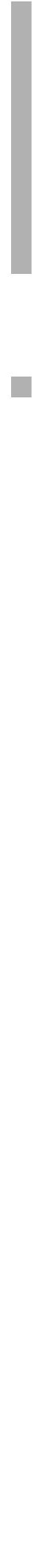

